\title{
Article
}

\section{Whistleblowing as a countermeasure strategy against food crime}

Soon, Jan Mei and Manning, Louise

Available at http://clok.uclan.ac.uk/17997/

Soon, Jan Mei ORCID: 0000-0003-0488-1434 and Manning, Louise (2017) Whistleblowing as a countermeasure strategy against food crime. British Food Journal, 119 (12). pp. 2630-2652. ISSN 0007-070X

It is advisable to refer to the publisher's version if you intend to cite from the work. http://dx.doi.org/10.1108/BFJ-01-2017-0001

For more information about UCLan's research in this area go to

http://www.uclan.ac.uk/researchgroups/ and search for < name of research Group>.

For information about Research generally at UCLan please go to http://www.uclan.ac.uk/research/

All outputs in CLoK are protected by Intellectual Property Rights law, including Copyright law. Copyright, IPR and Moral Rights for the works on this site are retained by the individual authors and/or other copyright owners. Terms and conditions for use of this material are defined in the policies page.

\section{CLoK}

Central Lancashire online Knowledge www.clok.uclan.ac.uk 


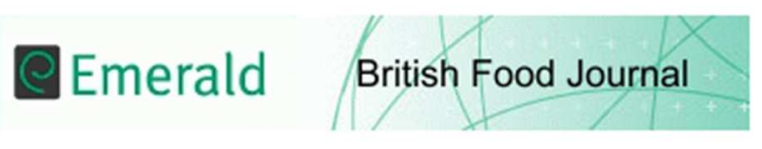

\section{Whistleblowing as a countermeasure strategy against food crime}

\begin{tabular}{|r|l|}
\hline Journal: & British Food Journal \\
\hline Manuscript ID & BFJ-01-2017-0001.R1 \\
\hline Manuscript Type: & General Review \\
\hline Keywords: & Food, crime, countermeasures, whistleblowing, Consumer Protection \\
\hline \multicolumn{2}{|c}{} \\
\end{tabular}

\section{SCHOLARONE ${ }^{\mathrm{Ix}}$ \\ Manuscripts}


2 Purpose: The aim of this research was to undertake a two-phase desktop review of literature

3 sources in order to conceptualise, frame, and critique existing whistleblowing models and

4 strategies and consider how whistleblowing strategies form part of an effective food crime

5 management system (FCMS) especially for small and medium sized organisations.

6 Design: Existing literature from academic sources, financial, healthcare, food industries has

7 been reviewed and critiqued in order to construct a conceptual framework that can inform 8 future empirical research.

9 Findings: Whistleblowing strategies can form an effective part of a FCMS. Appropriate 10 regulatory protection of those who whistleblow is crucial to not only safeguard individuals 11 but also to mitigate food crime and protect consumers from loss and potential harm. Barriers 12 to whistleblowing exist and if these are not addressed then individuals will be reluctant to 13 report food crime. Further empirical research is required to assess the influence of these and 14 other factors identified in this research and how they can be overcome.

15 Originality / Value: The framework will provide food industry practitioners with guidance on the effective application of whistleblowing strategies within a FCMS

\section{Keywords food, crime, countermeasure, whistleblowing, consumer protection,} 18 vulnerability

\section{Introduction}

Whistleblowing can be a mode of ethical resistance (Glazer and Glazer, 1989); a

21 vehicle to promote rights through movements such as consumer issues (Greenwood, 2015); or

22 a process to give a voice to animal rights and environmental concerns with regard to an 23 organisation's practices. Whistleblowers are seen as either individuals who undertake heroic 24 and noble deeds; or as malcontent, trouble-makers and misfits for exposing wrongdoing 25 (Zakaria, 2015). The term 'whistleblow' was coined by Nader et al., (1972) as disclosure by 26 organisational members of illegal, immoral, or illegitimate practices that are executed under 
27 the control of their employers, to persons or organisations that may be able to effect action as 28 a result of that disclosure (Miceli and Near, 1984; 1985; Near and Miceli, 1995; Near and 29 Miceli, 2016). Publically Available Specification (PAS) 1998 (2008:9) Whistleblowing 30 arrangements: Code of practice defines a whistleblowing concern as a "reasonable and honest 31 suspicion an employee has about a possible fraud, danger or other serious risk that threatens 32 customers, colleagues, shareholders, the public or the organisation's own reputation".

33 The authoritative individual that whistleblowers disclose to can be either internal to 34 the organisation: e.g. a supervisor (Soeken, 2014), manager (Miller, 2015; The Economist, 35 2015), or someone in the direct chain of command, or external such as regulatory officers or 36 independent supervisory bodies, inspectors, auditors, the police, MPs, consumer/citizen 37 groups, undercover reporters (Evans, 2014; Tang and Babich, 2014) or the media (Harris and 38 Barrett, 2009; PAS 1998, 2008). The Ethics Resource Centre (2012) report that 84\% of 39 private sector employees stated they would report any wrongdoing internally, but only $18 \%$ 40 would report to external parties. Whistleblowing is the only means of uncovering illicit 41 practices instigated or condoned by senior management (Moy, 2015). Organisations benefit 42 from early internal detection and prevention of criminal practices, so it is in their interest to 43 facilitate this means of detecting, preventing or mitigating criminal activity. Further 44 appropriate risk management with regard to criminal practice will deter potential food safety 45 issues, product recall, profit loss, and will maintain integrity, reputation, trust and brand value 46 for the organisation.

47 Organisations can implement a range of measures to reduce risk associated with 48 criminal behaviour, such as implementing additional or upgrading existing procedures. The 49 costs of a missed opportunity to address a criminal threat can be great: fines, requests for 50 compensation, higher insurance premiums, a regulatory investigation, lost jobs, lost profits 51 and even lost lives (PAS 1998:2008). External parties including regulators can benefit too 
52 from saved resources to investigate illicit activities, prosecution and public services costs.

53 The positive consequences of whistleblowing have been synthesized (Figure 1).

\section{$54 \quad$ Take in Figure 1}

55

The aim of this research was to undertake a two-phase desktop review of literature sources in order to conceptualise, frame, critique existing whistleblowing strategies and to consider how whistleblowing strategies could be integrated within an effective food crime management system (FCMS). The scope of the review included peer-reviewed articles, trade publications and online news items. Regulatory sources were reviewed to provide examples of legislative frameworks adopted to provide protection to whistleblowers. The second phase of the review included analysis of literature sources to provide an evidence base for historic examples of disclosure of criminal activity in the food chain and to critique the context in which they had occurred. This analytical approach led to a preliminary conceptual characterisation of whistleblowers and the factors that influence them. Lastly, the value of whistleblowing strategies in the food sector was considered and critiqued. In this context food crime has a wide focus and illegal activity can span food safety and food quality issues as equally as illicit activity and behaviour. The aim of this paper is not to contextualise what constitutes food crime specifically, but to look at the use of formal whistleblowing strategies within a FCMS to mitigate and, where possible prevent, illegal activity. If the food industry wants to effectively counter illicit and illegal practice, it must proactively ensure that internal reporting channels are available for staff. If these protocols do not exist, there is increased risk that external channels will be used to disclose wrongdoing and prevent an organisation from rectifying the problem internally first (Near and Miceli, 1985). This highlights the importance of whistleblowing as a management control mechanism to identify, mitigate and where 
76 possible deter wrongdoing. The next section of the paper focuses on examples of

77 whistleblowing in the food industry.

78

79

80

81

82

84

85

86

87

88

89

90

91

92

93

94

95

96

97

98

99

100

\section{Whistleblowing and whistleblowers}

Previous studies of whistleblowing mostly involve corporate or public sector malpractice such as corruption (Schultz and Harutyunyan, 2015), police agencies (Park and Blenkinsopp, 2009; Rothwell and Baldwin, 2006), accounting and financial reporting (Hwang et al., 2008, 2013), auditing (Alleyne et al., 2013; Arnold and Ponemon, 1991; Brennan and Kelly, 2007; Maroun and Solomon, 2014), government agencies (Cho and Song, 2015), and healthcare (Philipsen and Soeken, 2011). Within the health setting, McDonald and Ahern (2000) reported that health workers who reported misconduct were subjected to severe official reprisals including demotion, reprimand and referral to a psychiatrist. There were also instances of individuals experiencing threats, rejection by peers, pressure to resign and being treated as a traitor, or experiencing a lack of progression in their career. Hwang et al., (2008, 2013) assert that personal relationships, fear of retaliation and also media coverage discourage whistleblowing in Chinese society. Vinten (1996) associated the act of whistleblowing to a "bee-sting phenomenon" suggesting the approach can only be used once, before the act itself jeopardises the career of the whistleblower. Thus it is a high-stakes action and the potential consequences post-reporting (both positive and negative) will influence an individual's decision to either remain silent or to blow the whistle.

The PAWC (2013) report "Whistleblowing - The Inside Story" reviewed 1000 cases between August 2009 and December 2010 across all industry sectors. Food and beverage cases represented just $3 \%$ of the total cases so the results cannot be critiqued to reflect the food supply chain specifically, however overarching themes associated with whistleblowing can be determined. The whistleblowers' position was identified as executives (2\%), managerial (15\%), professional (26\%), skilled (27\%) unskilled (13\%) and administrative 
101 (8\%). This complies with the conclusions of Miceli et al., (2008) that whistleblowers are

102 more likely to be older, have more experience, work at supervisory levels, with higher pay, 103 and feel a sense of responsibility for reporting wrongdoing, and have greater knowledge of 104 appropriate internal channels. Whistleblowers can be motivated by moral purposes, 105 professional integrity (Motarjemi, 2014), courage (Zakaria, 2015), internal locus of control 106 (Chiu, 2003) and being proactive (Bjørkelo et al., 2010). Whistleblowers tend to have more 107 positive reactions to their work, be male and belonged to larger work groups (Miceli and 108 Near, 1988) with knowledge of circumstances and the individuals involved in fraudulent 109 practices (Zakaria, 2015). These characteristics highlight the individual or personal factors 110 that encourage whistleblowing a theme drawn upon later in the paper.

111 Wider constructs of organisational culture and subjective norms will influence the 112 intention to whistleblow. Subjective norm is the perceived social pressure to engage, or not in 113 a given behaviour in this case whistleblowing. Alleyne et al., (2013) suggest that norms 114 provide implicit guidelines and team norms are a moderating variable that create legitimate, 115 socially shared standards against which an individual's behaviour is measured (see Chatman 116 and Flynn, 2001). Thus a whistleblower on the one hand can be seen as a member of a team 117 or group who then goes against such team norms and attempts to change improper group 118 behaviour (Miceli and Near, 1984 cited by Greenwood, 2015) or alternatively follows an 119 organisational, team or group culture that welcomes whistleblowing. In previous research, the 120 Theory of Planned Behaviour (TPB) see Fishbein and Ajzen (1975); Ajzen and Fishbein, 121 (1980) and the Theory of Reasoned Action (TRA) see Ajzen (1985; 1991) have been used to 122 study how attitudes and subjective norms affects an individual's behaviour towards food 123 handling, consumption and purchase (Bianchi and Mortimer, 2015; Irianto, 2015; Mullan et 124 al., 2015), but not whistleblowing specifically in the food sector and this is worthy of further 125 study and explored further in this paper. 
126 Historic whistleblowing cases in the food industry suggest that whistleblowers

127 themselves suffer negative personal consequences including: depression and symptoms of 128 extremely poor mental health (Motarjemi, 2015a; 2015b); altered responsibilities (Dyck et al., 129 2010), refusal of pay increment, lack of peer support (Curtis, 2006), removal from usual 130 duties (Soeken, 2014), loss of employment (Motarjemi, 2014; Motarjemi, 2015a; Philipsen 131 and Soeken, 2011), stigma associated with being a "troublemaker" (Philipsen and Soeken, 132 2011); psychological harassment (Motarjemi, 2015a); resignation under duress (Dyck et al., 133 2010), threats of revenge and isolation (Tan and Ong, 2011), and possibly even murder 134 (Zhuang, 2012). Ponemon (1994) suggest that the nature and extent of the retaliation imposed 135 by the organisation's management or co-workers against the whistleblower is perhaps the 136 most significant determinant of a whistleblower's intention to disclose wrongdoing. 137 Furthermore, if whistleblowers seek personal redress from organisations for the personal 138 consequences of their disclosure, in the event that the case comes to court, corporate bodies if 139 they so choose have significant financial resources to "buy witnesses, delay the legal 140 processes and exert political pressure" leaving the employee in question unable to progress 141 with new employment or to have closure (Motarjemi, 2015a).

142 As part of this research a range of contemporary whistleblowing case studies across 143 the food industry have been drawn together. The cases reflect issues such as potential animal 144 welfare violations, bribery, corruption, and negligence with regard to food safety and food 145 quality issues (Table 1). Disclosure was conducted both internally, and also externally to 146 parties such as regulators or the media.

147 Take in Table 1

148

149 The breadth of the scope of examples shown in Table 1 demonstrates that it is difficult 150 to draw boundaries around, define and contextualize types of illicit behaviour associated with 
151 the food chain and that need to be addressed within an organisation's FCMS. Illicit behaviour

152 is not binary in terms of products, activities or actors and often reflects an acceptance of 153 customary illegality i.e. the acceptance and tolerance of illicit activities by predominantly 154 legal economic actors (Gregson and Crang, 2016). Factors that can drive customary illegality 155 including market competition and resource scarcity, inadequate governance, lack of sanctions 156 and low probability of discovery, rapid development of systems, logistics and technology, 157 data swamping and opacity (Charlebois et al. 2016; Manning et al. 2016; Manning, 2016; 158 Marvin et al. 2016). Opacity, even food crime itself, is driven by market dynamics and 159 seeking to survive in market economies with organisations that have better economies of scale 160 or operate as oligopolies (Manning et al., 2016).

161

\section{2. Food crime}

163 , Many illicit practices go undetected by both regulatory authorities and senior 164 management in food businesses. Hence, the discovery of such practices often relies on 165 individuals who report wrongdoing. Illicit activities elude formal enumeration and 166 measurement and circumvent institutional systems, regulations and associated enforcement 167 penalties (Feige, 1990). Further, the types of process verification activities undertaken in 168 market-focused second party audits and third party certification audits are constrained by the 169 scope of the system standards used, the planned nature, the time available and the frequency 170 of the audits, and the volume of data to be assessed (Manning, 2013; Manning and Soon, 171 2014). Illicit behaviour in the food supply chain arises as a result of misrepresentation 172 associated with:

173 - product integrity: the intrinsic quality attribute of totality or completeness $174 \quad$ (Manning and Soon, 2014); 
- process integrity: the activities undertaken to produce the food item encompassing

176

177

178

179

180

181

182

183

184

185

186

187

188

189

190

191

192

193

194

195

196

197

product testing methods require highly technical laboratory skills and the tests incur

198 considerable cost that supply chain pressures may not be able to bear, putting this option 
200 actors, thus unless it is part of a wider integrated FCMS it can be of limited value. Detection,

201 mapping and prevention activities can only be developed to address known issues or activities

202 making TACCP and VACCP also of limited value with regard to emerging and novel illicit

203 behaviour or entrepreneurial, enterprising, situational crime risk that is reactive, responsive

204 and specific to an organisation, the products it produces and the associated supply chain.

\section{3. Food crime management}

206 Food crime is undertaken by individuals and/or groups with varying criminal and 207 business modus operandi (Manning et al., 2016). FCMS can be both transactional and 208 transformational in nature. Transactional processes focus on the policies, procedures and 209 protocols, often called pre-requisites that drive formal management of food crime and 210 illegality and minimise risk (Manning et al., 2016). Conversely, transformational processes 211 encompass both formal and informal organisational culture and the role of employees, 212 irrespective of formal responsibilities, in enabling the organisation to maintain legal and 213 ethical practice and to detect, deter and disrupt criminal activity. Transformational elements 214 of a FCMS seek to inspire staff to consider that food legality and compliance is important and 215 to empower them to realise fully their specific role in ensuring compliance. Further 216 employees need to be aware that there is always the potential for emerging or re-emerging 217 crime challenges that must be effectively controlled, or where possible eliminated. Thus 218 whistleblowing strategies need to be embedded into both the transactional FCMS to ensure 219 that individuals are aware of the organisation's systems and procedures and also in the 220 transformational culture. Senior management must demonstrate both through their 221 commitment to the FCMS in terms of both engagement and appropriate resource allocation 222 and also in their overseeing of an effective business culture that demonstrates that in a 223 transparent business such strategies are welcomed and adopted as part of a wider corporate 224 disclosure discourse. Lamming et al., (2001) determine that there is a spectrum between 
225 transparency and opacity proposing that organisations can work in a form of corporate

226 "hinterland" in terms of their selective discourse. Therefore, crime risk increases in this

227 hinterland where transactional controls do not operate as intended and an informal culture can

228 not only just exist, but flourish.

229 Criminal organisations and networks complement and interact with traditional markets

230 and supply chains reducing transaction costs, and providing increased business opportunities

231 for both buyers and sellers (Williams, 2001). This entrepreneurial illicit approach (Manning et

232 al., 2016) is in contrast to the regulatory hierarchical mindset, bureaucratic rivalry and

233 competition, interagency antipathies, and hesitancy to share information, align databases or

234 coordinate enforcement operations (Williams, 2001). This makes crime mitigation activities

235 often less agile and reactive than the criminal networks they are seeking to disrupt. Whilst

236 FCMS are of value, integrated reactive measures such as whistleblowing protocols are

237 essential too.

238

239 3. Regulatory response towards protecting whistleblowers

$240 \quad 3.1$ European Union

241 The European Committee on Legal Co-operating (CDCJ) of the Council of Europe

242 developed the Recommendation $\mathrm{CM} / \operatorname{Rec}(2014) 7$ on the protection of whistleblowers

243 (Council of Europe 2014). Member states are encouraged to develop a robust national

244 framework that facilitates and protects whistleblowers. The Recommendation sets out a

245 number of key principles to ensure that: laws to protect whistleblowers cover a broad range of

246 information that is in the public interest; individuals have access to more than one channel to

247 report and disclose such sensitive information; mechanisms are in place to ensure reports and

248 disclosures are acted upon promptly; whistleblowers are entitled to have their identities kept

249 confidential by those to whom they report; and all forms of retaliation are prohibited as long 
250 as the individual whistleblower has reasonable grounds to believe in the accuracy and 251 credibility of the information.

252

Four EU member states have advanced whistleblower protection laws including the 253 United Kingdom (UK), Luxembourg, Romania and Slovenia. Of the other twenty-three EU 254 member states, sixteen include partial legal protection for whistleblowers in the public and/or 255 private sectors. For example, in October 2012, Italy included into its Anti-Corruption Law the 256 country's first ever provision intended to legally protect government employees against 257 negative implications linked to disclosure acts of wrongdoing. Previously, Italy has no 258 specific whistleblowing protection laws in place (World Law Group 2012). There were 259 cultural barriers in Italy where whistleblowing was viewed as treason (Osterhaus and Fagan, 260 2007) or betrayal (Dungan et al. 2015). Efforts by workers' unions in Italy to protect 261 whistleblowers led to the proposed amendments to Italy's Anti-Corruption Law (G20 Anti262 Corruption Action Plan, 2010). The Italian public sector can report wrongdoing as long as it is 263 not committed out of defamation or intent to harm a person's right to privacy. The act 264 however, does not apply to the private sector. There has been a call by Transparency 265 International Italia for wider protection covering employees in both public and private sectors 266 (Worth, 2013). In France, a new anti-corruption law was adopted on December 9, 2016 (Law 267 2016-1691) the so called "Law Sapin II". This strengthened the law with regard to 268 whistleblowing particularly against discrimination or retaliation against whistleblowers. The 269 law lays down precise requirements that provide context to whether a whistleblower would be 270 entitled to protection under the law (WIN, 2017a). The remaining seven countries (i.e. 271 Bulgaria, Finland, Greece, Lithuania, Portugal, Slovakia and Spain) have limited or no legal 272 frameworks (Transparency International's Secretariat, 2013).

273 In the UK, the Public Interest Disclosure Act 1998 protected workers from unfair 274 treatment or victimisation from their employer if they reported wrongdoing in the workplace 
275 (FSA, 2016a). Employees, who are aware of wrongdoing within the food industry, including

276 suspecting or witnessing of a breach in welfare of an animal at slaughter, can disclose that 277 wrongdoing under the protection the Act affords if they raise their concerns in accordance 278 with the Act's provisions. A given act of disclosure is a qualifying disclosure for 279 whistleblowing if the worker reasonably believes one or more of the following has occurred: 280 criminal offence, breach of a legal obligation, miscarriage of justice, danger to the health and 281 safety of any individual, damage to the environment and deliberate concealment of 282 information is happening currently, occurred in the past or is likely to happen in the future 283 (FSA, 2016b). In implementing this Act, the UK Food Standards Agency (FSA) has extended 284 protection to food industry workers, whether or not the information is confidential, and 285 whether or not the wrongdoing occurred in the UK itself (Motarjemi, 2014).

In the aftermath of the 2013 European horsemeat incident, the FSA's National Food 287 Crime Unit (NFCU) was created as a result of the recommendations in the Elliott Review 288 (2014) to help ensure that prevention measures are put in place to protect consumers from 289 food fraud (FSA n.d.). In addition to setting up the Unit, the Elliot Review strongly 290 recommended firstly that any incident of suspected and known food crime should be reported 291 directly by staff to their own employers and secondly that customers can report to 292 management any potential concerns (Elliot Review, 2014). Further there should be 293 encouragement of a culture within the food industry that questions sourcing in its supply 294 chain and also wider food integrity. However, the mechanisms that enable whistleblowing 295 and reporting with the food industry, including regulatory bodies, need developing further. 296 The whistleblowing procedures and facilities provided by the NFCU enable potential 297 whistleblowers to disclose confidentially (FSA, 2016a, 2016b) dishonesty at any stage within 298 the production or supply of food, drink or animal feed (FSA, 2016b). Members of the public 299 are encouraged to whistleblow or to report suspicions of food fraud to their local authority or 
300 the NFCU (FSA, 2016a). All intelligence received is logged on the Food Fraud Database 301 (FFD) and the identity of the whistleblower protected at all times. Outcomes are logged on 302 the Food Fraud Database and if requested reported back to the whistleblower (FSA, 2016a; 303 IMTA, 2016). Food safety and quality concerns can also be raised via the FSA's "Report a 304 food problem" site targeted specifically on local food businesses (FSA, 2016c). The UK FFD 305 serves as an important source of intelligence and a tool to detect emerging patterns of 306 fraudulent and criminal activities (FSA, 2016a, d). In 2011, there were 54 complaints ans in 307201281 such complaints. The food fraud team handled 134 cases in 2013 that comprised sale 308 of unfit food (42), general hygiene issues (39), mis-description (13), illegal re-dating of food 309 (7), single cases each of adulteration and authenticity (Elliot Review, 2014).

\subsection{United States}

The United States (US) has one of the most comprehensive whistleblower provisions developed in relation to the Sarbanes and Oxley Act (SOX) and was passed by the US congress to protect general public and shareholders from fraudulent practices in financial markets (Sarbanes-Oxley Act, 2002; Schultz and Harutyunyan, 2015). Under the US Food and Drug Administration (FDA), the Food Safety Modernization Act (FSMA, 2011) Section 402 prohibit retaliation by food businesses against whistleblowers who have: provided information relating to any violation of the Food, Drug and Cosmetic Act (FD\&C) to the employer, the Federal Government, or the attorney general of a State; testified, assisted, or participated in a proceeding concerning a violation of the FD\&C or; objected to or refused to participate in any activity that he or she reasonably believed to be in violation of the FD\&C (FSMA, 2011; Moy, 2015; OSHA, 2014). This regulation has driven the development of whistleblowing procedures to comply with the US Sarbanes-Oxley Act (Osterhaus and Fagan, 323 2007).

$324 \quad 3.3$ Serbia 
325 On 25 November 2014, the Parliament of Serbia adopted the Law on the Protection of

326 Whistleblowers, the law coming into force in June 2015 (WIN, 2017b). The legislation

327 clearly describes the act of whistleblowing, the rights and entitlements to protection not only

328 of the whistleblower themselves, but also the officials who are then required to perform a duty

329 to investigate. Indeed every employer with more than ten employees by law is required to

330 endorse an internal whistleblowing procedure. The procedure must be in a visible, accessible

331 location for all employees and it must also be posted on the company website if the company

332 has one. Fines can be imposed if businesses fail to undertake this requirement. There are also

333 strict timings set for competent authorities to adhere to in the event of external disclosure of

334 wrongdoing.

335

336 4. Market response towards protecting whistleblowers

337 The UK Department of Business, Innovation and Skills (BIS) issued a report in March

3382015 titled "Whistleblowing: Guidance for Employers and Code of Practice (BIS, 2015). The

339 report states that whilst a voluntary requirement it is good business practice to create an open,

340 transparent and safe working environment through implementing a whistleblowing policy in

341 the workplace. Depending on the nature and size of the business, PAS 1998 (2008) outlines

342 that overall responsibility for enabling whistleblowing should rest with either the Board,

343 Chief Executive, Group Secretary, with routine responsibility falling to the human resources

344 department. In a small food business with both strategic and operational roles filled by one or

345 two individuals this could prove more difficult to disassociate.

346 In this research the development of whistleblowing policies as a market response has

347 been considered with three cases using publically available policies for Associated British

348 Foods (ABF) plc, Home Retail Group (HRG) plc, and Tesco plc. ABF (2016) state that the

349 purpose of their voluntary whistleblowing policy is to protect individuals working within their 
350 organisation when raising matters of public interest to stop malpractice and wrongdoing. The 351 organisation outlines a five step plan:

- Step 1: Inform manager or head of department;

- Step 2: raise the matter with alternative internal contacts if unable to raise with line manager;

- Step 3: Initial assessment and determination of corporate action; and

- Step 4: Opportunity if response/outcome is not deemed sufficient to raise the matter

Expolink are a privately owned organisation, founded in 1995, that specialise in providing

whistleblowing hotlines supporting over $20 \%$ of FTSE 100 companies, many FTSE 250 and

Fortune 500 companies, local authorities, government departments, police forces and multinational corporations (Expolink, 2016a). Expolink (2016b) report that 3.3 million employees made contact in the January-June 2016 period with an incidence rate of 1.24 reports per 1000 malpractice $(9.9 \%)$, fraud $(5.1 \%)$, theft $(3.7 \%)$, security $(1.6 \%)$, corruption $(1.3 \%)$, other (78.4\%). The frequency of theft and fraud from 2009 - 2016 (Table 2) shows a reporting frequency of $10 \%$ in 2009 down to $3.7 \%$ of contacts in 2016 and for fraud a reporting frequency of $8 \%$ in 2009 down to $5 \%$ in 2016.

372

HRG (2016) also has a five step approach for raising issues: 
375 - Step 2: Raise with line manager's manager either as a first contact or if individual

376

377

378

379

380

381

382

383

384

385

386

387

388

389

390

391

392

393

394

395

396

397

398

399 raising issue is unhappy with the initial response in Step 1;

- Step 3: Raise at Director level if these two steps have not given the response to the individuals satisfaction;

- Step 4: Internal enquiry or more formal investigation; and

- Step 5: Formal arrangements for a third party legal advice organisation in this case Public Concern at Work (PCAW). This organisation can give advice on external disclosure. PCAW are a charity established in 1993 (PCAW, 2016).

The Whistleblowing Tesco Colleague and Suppliers Protector Line Policy outlines how Protector Line, a confidential telephone and email service, operates for both internal and external stakeholders (Tesco, 2016). Suppliers can report concerns on a website that is managed by Expolink. Thus all three organisations have similar reporting systems using a specific external contractor to address whistleblowing that is either not raised internally, or has been raised but not addressed to the satisfaction of the person raising the concerned. It is important in all these cases to differentiate between an employment grievance and an instance of whistleblowing. PAS 1998:2008 states that an employment grievance is a dispute or private complaint regarding the employee's own employment position and therefore it has no additional public interest dimension. These cases show that a positive whistleblowing culture and environment associated with an ethical culture practiced by the organisation encourages staff to have strong conscience to report wrongdoing (Miceli et al., 2008; Mendonca, 2011). Depending on national culture, some societies fear shame but not necessarily guilt (e.g. China is a shame-based society), hence shame can be used as an effective mechanism to enforce staff compliance (Tang and Babich, 2014). In contrast, a culture with supportive supervisors, appropriate formal structures for reporting (Brennan and Kelly, 2007) and protection afforded to whistleblowers (Cho and Song, 2015; Zakaria, 2015) will drive whistleblowers to report 
400 wrongdoing. The challenge with purely voluntary governance measures, rather than the 401 Serbian approach, that each organisation will develop their own discrete protocols that can 402 vary in their degree of efficacy. Thus personal (individual), organisational/cultural and 403 situational factors (Dungan et al. 2015). are now explored further in the paper.

404

405 5. Whistleblowing models

406 A number of whistleblowing models exist in the literature that have been designed to address 407 mainly corporate fraud in the financial, business and public sectors but none specifically for 408 food industry. These have been analysed within this research (Table 3). The models often 409 reflect individual (Henik, 2015), organisational (Alleyne et al., 2013; Brennan and Kelly, 410 2007) and cultural factors (Hwang et al., 2008). Although many studies have applied the TRA 411 and TPB to food and food service sectors, little research has dealt with their application to 412 whistleblowing. Table 3 then provides the context for the potential application within a food 413 production or supply chain setting. Henik (2015 citing Goldberg et al., 1999) describes three 414 types of whistleblower: (i) the strategic moral guardian (SMG); (ii) the fed-up vigilante 415 (FUV) and (iii) the inactive individual called in this research as the servant of two masters 416 (STM) see Table 4.

\section{Take in Tables 3 and 4}

418

419 Henik (2015) draws upon existing theory to discuss a five-stage whistleblowing model 420 around which organisational whistleblowing strategies, such as those described in this paper 421 for $\mathrm{ABF}$ and $\mathrm{HRG}$, can be developed.

\section{$422 \quad$ Stage 1 - A trigger event}

423 A trigger event is as an event that is deemed by an individual or group to be 424 problematic (Henik, 2015). Factors that can trigger whistleblowing include internal 
425 motivation (Schultz and Harutyunyan, 2015), personal responsibility (Hwang et al., 2008, 426 2013), seriousness of wrongdoing (Graham, 1986; Curtis, 2006) and loyalty towards the 427 company (Dungan et al., 2015) see Table 3. An individual trigger may be clear in terms of its 428 legality or the trigger may be opaque creating uncertainty as to whether to raise the issue with 429 others (PAWC, 2013).

\section{Stage 2 - Determining of appropriate action}

431 The whistleblower may be concerned whether complicity means that they themselves 432 may face sanction and this may limit action. PAWC (2013) identify in their study that in only $4338 \%$ of the cases they examined the whistleblower admitted that they have been involved in the 434 issue themselves. Other factors that affect willingness to take action are fear of reprisal or 435 retailiation, being unsure whether the activities warrant action, uncertainty over what action is 436 possible and appropriate and the opportunity cost versus the benefit or having little faith that 437 any corrective action will be done (PAWC, 2013; Henik, 2015 citing March and Simon, 1958; 438 Latané and Darley, 1970; Miceli and Near, 1992). However, Henik (2015) argues it is 439 emotion and value conflict that actually motivates action or inaction. Stage 2 is a crucial stage 440 in the whistleblowing process as individual, organisational and situational factors play a 441 mediating role in encouraging or discouraging potential whistleblowers.

\section{$442 \quad$ Stage 3 - Action of whistleblowing}

443 PAWC (2013) suggest that a whistleblower's position in an organisation will be a 444 factor that influences the route they follow to raise their concern. The group of workers they 445 identified as less likely to approach their line manager or senior management was unskilled 446 workers. In fact their study suggested that unskilled and skilled workers were more likely to 447 approach the individual(s) who they thought was the wrongdoer or disclose to an independent 448 body rather than other workers, or finally a regulatory body. This highlights if people are to 449 come forward with concerns that as well as transactional structure in the FCMS, 
450 transformational elements such as an open culture, training and coaching are required.

451 Administrative workers were more likely to approach senior management or a union 452 representative through and use the employment grievance procedure rather than follow a 453 whistleblowing process or a specialist channel. This may be due to the type of trigger that 454 they were reporting, or greater awareness of policy and practice, but they were reticent about 455 approaching their line manager. Managers and executives were more likely to raise their 456 concern initially to senior management and also more likely to approach the media. 457 Ultimately, in order to prevent or reduce loss of profit, reputation and trust with customers, 458 the food industry should aim to resolve the problems internally whilst ensuring confidentiality 459 for the whistleblowers.

460 Stage 4 - Organisational reaction to action

461 PAWC (2013) state that from their dataset whistleblowers felt that no action was taken after 462 the first attempt of internal disclosure in $74 \%$ of cases and this rose to $80 \%$ when it was 463 unskilled workers who wore making the disclosure. At the third attempt in $44 \%$ of cases 464 whistleblowers felt there was no organisational reaction; this was zero cases at executive 465 level, but still $80 \%$ for unskilled workers. The work of Henik (2015) shows that the 466 organisation needs to make sure that they do not alienate the individuals who seek to disclose 467 potential wrongdoing especially as this can then provide personal motivation for justice and 468 restitution. Ensuring there is full confidence in the management process surrounding 469 whistleblowing is critical.

\section{Stage 5 - Whistleblowers response}

471 The whistleblowers who actively report on wrongdoing are the SMG or FUV (see 472 Table 4 for definitions). Inaction can be due to conflicting emotions and values. Therefore, a 473 FCMS encompassing both transformational and transactional approaches will be beneficial to 474 encourage the STM to act. Henik (2015) asserts that a differentiation of emotion will 
475 influence the methods and aims of a given whistleblowing disclosure and the whistleblowers

476 response and whilst SMG retain their focus on halting wrongful activities, FUV will focus on

477 the desire for restitution. The causal factors that underpin the five steps outlined above and

478 their interrelationship with an associated FCMS have been conceptualised in Table 5 and

479 represented visually in Figure 2. Understanding these factors will assist food industry

480 practitioners and regulators to develop policies, guidance and best practice. These

481 transactional and transformational elements are now explored.

482 Take in Table 5 and Figure 2

483 Adoption of crime countermeasures is based unique assessment by each organisation,

484 the organisation's risk appetite and the unique crime opportunity of the given supply system

485 (Spink et al., 2016). These countermeasures then need to be integrated into an effective

486 FCMS. Countermeasures are intended to reduce criminal opportunity so if appropriate

487 countermeasure strategies are to be developed and adopted then it is important to establish

488 both the type of crime and the typology of the criminal (Manning, 2016; Manning et al.,

489 2016; Spink et al., 2015). Organisations should as part of this approach recognise and

490 accommodate effective whistleblowing channels. Failure to do so could lead to what

491 Motarjemi (2015a) describes as "wild whistleblowing” i.e. extra-legal or illegal approaches to

492 reporting or disclosing information through internet "leaking" type approaches. Further, a

493 condoning of negative behaviour towards whistleblowers leads to a repressive, unhealthy

494 management culture (Motarjemi, 2015b) that ultimately will stifle employee loyalty, and the

495 potential for innovation, creativity and new ideas within the organisation.

496 Loehr and Kaye (2011) have proposed the use of the 5 C's framework in order to 497 encourage and build a loyal and committed workforce. This can be extended to consider the 498 integration of a whistleblowing strategy within a FCMS. The five "C's have been adapted in 499 this context: 
- Commit to employees' professional growth and success so that they feel personally

501

502

503

504

505

506

507

508

509

510

511

512 invested in by the organisation and then as a result less likely to be compelled to

513 The 5 Cs demonstrate the transformational infrastructure that needs to be in place to underpin

514 the FCMS. A cultural shift towards an encouraging, and supportive environment for 515 whistleblowing can provide a source of intelligence that can help organisations to prevent 516 potential public health implications, loss of profit and protect the reputation of company. In 517 the development and implementation of a FCMS, small and medium sized food companies 518 may not have the resources and knowledge necessary to carry out risk assessments using tools 519 such as VACCP or TACCP, but with appropriate industry guidance they can more readily 520 implement a whistleblowing protocol within their organisation and with their suppliers.

521 With appropriate induction and refresher training, and ongoing coaching an 522 effective, and reactive FCMS can be developed which is appropriate to the situational needs 523 of every business. Indeed PAS 1998:2008 states that where the business is small and everyone 524 is known by name, transformational management processes may be strong enough so that a 
525 complicated written protocol is not required, instead a simple statement will be of value to 526 that simply explains: the difference between whistleblowing and a private complaint with 527 management; how an employee can make an external disclosure and the benefits of an 528 independent helpline that facilitates the disclosure process; that whistleblowing is not a 529 mechanism for undermining managers; and the challenges with maintaining confidentiality.

530

531 6. Concluding remarks

532 Whistleblowing exposes illegal, inappropriate and fraudulent practices with the goal that 533 private and/or public exposure will force change. Many of these criminal practices go 534 undetected by regulatory authorities and at times senior management of an organisation. 535 Conventional behavioural models such as TRA and TPB can be extended to include 536 individual, organisational, cultural and situational factors to study whistleblowing intention 537 among food production workers and this has been the approach used in this conceptual paper 538 in developing Figure 2. Greater understanding not only the forward process, but also the 539 feedback loops, and the situational factors of influence will assist food industry practitioners 540 in developing effective FCMS that include a whistleblowing strategy. Therefore appropriate 541 regulatory protection of those who engage in whistleblowing activities is crucial to both 542 mitigate food crime and protect consumers from loss and potential harm. Without considering 543 the specific difficulties that arise and addressing the existing barriers to whistleblowing it is 544 unlikely that the whistleblowing can become an effective strategy for addressing food crime. 545 Therefore further empirical research is required to assess the influence of these barriers and 546 how they can be overcome. The model in this paper provides opportunity for such primary 547 research.

548 


\section{References}

550 
599 Charlebois, S., Schwab, A., Henn, R., and Huck, C. W. (2016). "Food fraud: An exploratory 600 study for measuring consumer perception towards mislabelled food products and influence on 601 self-authentication intentions". Trends in Food Science and Technology, Vol. 50, No. 1, pp. 602 211-218.

603

604

605

606

607

608

609

610

611

612

613

614 Council of Europe (2014), "Recommendation CM/Rec (2014) 7 of the Committee of

615

616

617

618

619

620

621

622

623

624

625

626

627

628

629

630

631

632

633

Chatman, J. A., and Flynn, F. J. (2001). "The influence of demographic composition on the emergence and consequences of cooperative norms in work teams", Academy of Management Journal, Vol. 44, No. 5, pp. 956-974.

Chiu, R. K. (2003). "Ethical judgment and whistleblowing intention: Examining the moderating role of locus of control", Journal of Business Ethics, Vol. 43, No. 1, pp. 65-74.

Cho, Y.J. and Song, H.J. (2015), "Determinants of whistleblowing within government agencies", Public Personnel Management, Vol. 44 No. 4, pp. 450-472. Ministers to member States on the protection of whistleblowers", available at: http://www.coe.int/t/dghl/standardsetting/cdcj/CDCJ\%20Recommendations/CMRec(2014)7E .pdf (accessed 4 March 2016).

Curtis, M.B. (2006), “Are audit-related ethical decisions dependent upon mood?” Journal of Business Ethics, Vol. 68 No. 2, pp. 191-209.

Dungan, J., Waytz, A. and Young, L. (2015), “The psychology of whistleblowing”, Current Opinion in Psychology, Vol. 6, No. 1, pp. 129-133.

Dyck, A., Morse, A. and Zingales, L. (2010), "Who blows the whistle on corporate fraud?" Journal of Finance, Vol. 65 No. 6, pp. 2213-2253.

Eisenhammer, S. (2017), "Whistleblower in meat industry scandal takes on powerful industry" available at: http://uk.reuters.com/article/us-brazil-corruption-food-whistleblower$\underline{\text { idUKKBN16V2FO }}$ (accessed on 18 April 2017)

Elliot Review (2014), "Elliot review into the integrity and assurance of food supply networks - final report. A national food crime prevention framework", available at:

634 https://www.gov.uk/government/uploads/system/uploads/attachment_data/file/350726/elliot-

635 review-final-report-july2014.pdf (accessed 5 March 2016).

636

637 Ethics Resource Center (2012), "Inside the mind of a whistleblower. A supplemental report of 638 the 2011 National Business Ethics Survey", available at: http://www.kkc.com/wp-

639 content/uploads/2014/08/ERC_Inside-The-Mind-Of-A-Whistleblower.pdf (accessed 4 March 640 2016).

641

642

643

644

645

646

Evans, S.J. (2014), "Shanghai shuts factory 'supplying out-of-date meat to American fast food chains including McDonald's and KFC",, Mail Online 22 July 2014, available at: http://www.dailymail.co.uk/news/article-2699623/McDonalds-KFC-China-face-new-foodscandal.html (accessed 6 March 2016). 
647 Expolink (2016a) Expolink website Available at:

648 http://expolink.co.uk/whistleblowing/whistleblowing-hotline/ Accessed on 28 November

6492016

650

651 Expolink (2016b) Expolink Whistleblowing benchmark report Available at: 652 http://www.expolink.co.uk/Expolink-Whistleblowing-Benchmarking-Report.pdf Accessed 28 653 November 2016

654

655

656

657

658

659

660

661

662

663

664

665

666

667

668

669

670

671

672

673

674

675

676

677

678

679

680

681

682

683

684

685

686

687

688

689

690

691

692

693

694

695

Expolink (2014), Expolink Whistleblowing benchmark report Available at: http://expolink.co.uk/whistleblowing/blog/whistleblowing-benchmarking-report-2014/

(accessed 28 November 2016)

Farnsworth, S. (2016), "Echuca abattoir under investigation after whiste-blower filmed animal mistreatment." Available at: http://www.abc.net.au/news/2016-11-23/echuca-abattoirunder-investigation-after-animal-mistreatment/8047318 (accessed 18 April 2017)

Feige, E.L., 1990. Defining and estimating underground and informal economies: The new institutional economics approach. World development, Vol. 18, No. 7, pp.989-1002.

Farrell, D., \& Petersen, J. C. (1982). "Patterns of political behavior in organizations". The Academy of Management Review, Vol. 7, No. 1, pp. 403-412.

Fishbein, M. and Ajzen, I. (1975), Belief, attitude, intention and behaviour: An introduction to theory and research. Addison-Wesley Publishing Company, MA.

FSMA, Food Safety Modernization Act (2011), "FDA Food Safety Modernization Act P.L. 111-353 January 4, 2011. Sec. 402. Employee protections", available at:

http://www.whistleblowers.gov/acts/fda_402.html (accessed 4 March 2016).

FSA (n.d.) Food Standards Agency, "The National Food Crime Unit”, available at:

www.food.gov.uk/enforcement/the-national-food-crime-unit (accessed 21 January 2016).

FSA, Food Standards Agency (2016a), "Reporting food fraud", available at:

https://www.food.gov.uk/enforcement/the-national-food-crime-unit/foodfraud (accessed 4 March 2016).

FSA, Food Standards Agency (2016b), "Whistleblowing", available at:

https://www.food.gov.uk/enforcement/the-national-food-crime-unit/foodfraud/whistleblowing (accessed 4 March 2016).

FSA, Food Standards Agency (2016c), "Report a food problem", available at:

http://www.food.gov.uk/enforcement/report-problem (accessed 30 August 2016).

FSA, Food Standards Agency (2016d), "The National Food Crime Unit", available at: https://www.food.gov.uk/enforcement/the-national-food-crime-unit (accessed 30 August 2016).

G20 Anti-Corruption Action Plan (2010), "Protection of whistleblowers: Study on whistleblower protection frameworks, compendium of best practices and guiding principles 
696 for legislation", available at: https://www.oecd.org/g20/topics/anti-corruption/48972967.pdf

697 (accessed 5 May 2016).

698

699 Glazer, M. P., and Glazer, P. M. (1989). The whistleblowers: Exposing corruption in 700 government and industry. New York: Basic Books, Inc. $\square$

701

702

703

704

705

706

707

708

709

710

711

712

713

714

715

716

717

718

719

720

721

722

723

724

725

726

727

728

729

730

731

732

733

734

735

736

737

738

739

Goldberg, J. H., Lerner, J. S., and Tetlock, P. E. (1999). "Rage and reason: The psychology of the intuitive prosecutor". European Journal of Social Psychology, Vol. 29, No. 1, pp. 781795 .

Graham, J.W. (1986), "Principled organization dissent: A theoretical essay", Research in Organizational Behaviour, Vol. 8, No. 1, pp. 1-52.

Greenwood, C.A. (2015), "Whistleblowing in the Fortune 1000: What practitioners told us about wrongdoing in corporations in a pilot study", Public Relations Review, Vol. 41, No. 1, pp. $490-500$

Grundy, H.H., Kelly, S.D., Charlton, A.J., Donarski, J.A., Hird, S.J. and Collins, M.J. (2012), "Food authenticity and food fraud research: Achievements and emerging issues", Journal of the Association of Public Analysts, Vol. 40, No. 1, pp. 65-68.

Harris, D. and Barrett, K. (2009), "Former manager says peanut plant complaints ignored", ABC News, available at: http://abcnews.go.com/GMA/story?id=6888169\&page=1 (accessed 2 March 2016).

Henik, E. (2015), “Understanding whistle-blowing: a set-theoretic approach”, Journal of Business Research, Vol. 68 No. 1. pp. 442-450

Hirschman, A. O. (1970). Exit, voice, and loyalty: Responses to decline in firms, organizations, and states. Cambridge, MA: Harvard University Press. $\square$

Home Retail Group (2016), Whistleblowing Policy, Available at: https://www.homeretailgroup.com/crreports/2007/pdfs/HomeRetailWhistleblowingPolicyOct 2007.pdf (Accessed on 27 November 2016)

Hwang, D.B.K., Staley, A.B., Tsai, Y. and Chui, C.L. (2013), "A comparative study of the propensity of whistle-blowing empirical evidence from China, Taiwan and the United States", International Journal of Accounting and Financial Reporting, Vol. 3 No. 2, pp. 202-204.

Hwang, D., Staley, B., Te Chen, Y. and Lan, J. (2008), "Confucian culture and whistleblowing by professional accountants: an exploratory study," Managerial Auditing Journal, Vol. 23 No. 5, pp. 504-526.

IMTA, International Meat Trade Association (2016), "Food fraud and suspicious activity 740 reporting", available at: http://www.imta-uk.org/food-fraud-reporting (accessed 12 November 741 2016).

742

743

744

745

Irianto, H. (2015), “Consumers' attitude and intention towards organic food purchase: An extension of Theory of Planned Behavior in gender perspective", International Journal of Management, Economics and Social Sciences, Vol. 41, No. 1, pp. 17-31. 
Johnson, R. (2014), Food Fraud and "Economically Motivated Adulteration" of Food and Food Ingredients, Congressional Research Service, CRS Report January, 10, 2014

Kelly, S., Heaton, K. and Hoogewerff, J. (2005), "Tracing the geographical origin of food: The application of multi-element and multi-isotope analysis", Trends in Food Science and Technology, Vol. 16 No. 12, pp. 555-567.

Latané, B., and Darley, J. M. (1970). The unresponsive bystander: Why doesn't he help? New York: Appleton-Century Crofts.

Lamming, R.C., Caldwell, N.D., Harrison, D.A., Phillips, W. (2001). “Transparency in supply relationships: concept and practice”. Journal of Supply Chain Management, Vol. 37, No. 3, pp. 4-10.

Loehr A, and Kaye J. (2011). Managing the unmanageable: How to motivate even the most unruly employee. Pompton Plains: Career Press.

Manning, L., Smith, R., and Soon, J.M (2016). "Developing an Organizational Typology of Criminals in the Meat Supply Chain”, Food Policy, Vol.59, No. 1, pp. 44-54

Manning L. (2016), "Food Fraud, policy and food chain”, Current Opinions in Food Science, Vol. 10, No. 1, pp. 16-21

Manning, L. and Soon, J.M. (2016), "Food safety, food fraud, and food defense: A fast evolving literature", Journal of Food Science, Vol. 81, No. 4, R823-R834

Manning, L and Soon, J.M, (2014), "Developing systems to control food adulteration", Food Policy, Vol. 49, No. 1, pp. 23-32

Manning, L., (2013), "Development of a food safety verification risk model”, British Food Journal, Vol. 115, No. 4, pp. 575-589

March, J. G., and Simon, H. A. (1958). Organizations. New York: Wiley.

Maroun, W. and Solomon, J. (2014), "Whistleblowing by external auditors: Seeking legitimacy for the South African audit profession", Accounting Forum, Vol. 38 No. 2, pp. 109-121.

Marvin, H. J., Bouzembrak, Y., Janssen, E. M., van der Fels-Klerx, H. J., van Asselt, E. D., and Kleter, G. A. (2016). "A holistic approach to food safety risks: Food fraud as an example”, Food Research International, Vol. 89, No. 1, pp. 463-470.

McDonald, S. and Ahern, K. (2000), “The professional consequences of whistleblowing by nurses”, Journal of Professional Nursing, Vol. 16, No. 6, pp. 313-321.

Mendonca, M. (2011), "Preparing for ethical leadership in organizations", Canadian Journal of Administrative Science, Vol. 18 No. 5, pp. 266-276. 
796 Miceli, M.P., Near, J.P. and Dworkin, T.M. (2008). Whistle-blowing in organization.

797 Psychology Press, Taylor \& Francis Group, New York.

798

799 Miceli, M. P., and Near, J. P. (1992). Blowing the whistle: The organizational and legal

800 implications for companies and employees. Lexington, MA: Lexington Books.

801

802

803

804

805

806

807

808

809

810

811

812

813

814

815

816

817

818

819

820

821

822

823

824

825

826

827

828

829

830

831

832

833

834

835

836

837

838

839

840

Miceli, M.P. and Near, J.P. (1985), “Organizational dissidence: The case of whistle-blowing”, Journal of Business Ethics, Vol. 4 No. 1, pp. 1-16.

Miceli, M.P. and Near, J.P. (1984), "The relationships among beliefs, organizational position, and whistle-blowing status: A discriminant analysis", Academy of Management Journal, Vol. 27 No. 4, pp. 687-705.

Miller, H. (2015), "Nestle CEO takes stand in harassment suit brought by executive", Bloomberg Business, available at: http://www.bloomberg.com/news/articles/2015-12-

16/nestle-ceo-takes-stand-in-harassment-suit-brought-by-executive (accessed 4 March 2016).

Motarjemi, Y. (2015a), "The real problem with whistleblowing”, le News 19/02/2015, available at: http://lenews.ch/2015/02/19/the-real-problem-with-whistleblowing/ (accessed 21 April 2017)

Motarjemi, Y. (2015b), “Workplace abuse.It's happening in Switzerland too”, le News 18/08/2015, available at: http://lenews.ch/2015/08/28/workplace-abuse-its-happening-inswitzerland-too/ (accessed 21 April 2017)

Motarjemi, Y. (2014), "Whistleblowing. Food safety and fraud”, Food Safety Magazine, June/July, available at: http://www.foodsafetymagazine.com/magazine-archive1/junejuly2014/whistleblowing-food-safety-and-fraud/\#References (accessed 4 March 2016).

Moy, G. (2015), "Whistleblowing and the food industry", The World of Food Science, available at: http://worldfoodscience.com/article/whistleblowing-and-food-industry (accessed 13 March 2016).

Moyer, D. C., DeVries, J. W., and Spink, J. (2017). The economics of a food fraud incidentCase studies and examples including Melamine in Wheat Gluten. Food Control, Vol. 71, No. 1, pp. 358-364.

Mullan, B., Allom, V., Sainsbury, K. and Monds, L. A. (2015), "Examining the predictive utility of an extended theory of planned behaviour model in the context of specific individual safe food handling”, Appetite, Vol. 90, No. 1, pp. 91-98.

Nader, R., Petkas, P.J. and Blackwell, K. (Eds.). (1972). Whistle blowing: The report of the conference on professional responsibility, Grossman Publishers, New York, pp. 39-136.

Near, J.P. and Miceli, M.P. (2016), "After the wrongdoing: What managers should know

841

842

843

844 about whistleblowing”, Business Horizons, Vol. 59 No. 1, pp. 105-114.

845

Near, J.P., Rehg, M.T., Van Scotter, J.R. and Miceli, M.P. (2004), "Does type of wrongdoing affect the whistle-blowing process?" Business Ethics Quarterly, Vol. 14 No. 2, pp. 219-242. 
846 Near, J.P. and Miceli, M. (1985), “Organizational dissidence: the case of whistle-blowing”, 847 Journal of Business Ethics, Vol. 4 No. 1, pp. 1-16.

848

849

850

851

852

853

854

855

856

857

858

859

860

Nitsch, D., Baetz, M. and Hughes, J. C. (2005), "Why code of conduct violations go unreported: A conceptual framework to guide intervention and future research", Journal of Business Ethics, Vol. 57, No. 1 pp. 327-341.

OSHA, Occupational Safety and Health Administration (2014), "Procedures for handling retaliation complaints under Section 402 of the FDA Food Safety Modernization Act", available at:

www.osha.gov/pls/oshaweb/owadisp.show_document?p_table=FEDERAL_REGISTER\&p_i $\mathrm{d}=24284$ (accessed 13 March 2016).

861 http://www.right2info.org/resources/publications/publications/09 12 01\%20ti-

862 Alternative\%20WB\%20protection.pdf (accessed 5 May 2016).

863

864

865

866

867

868

Park, H. and Blenkinsopp, J. (2009), "Whistleblowing as planned behaviour - A survey of South Korean police officers", Journal of Business Ethics, Vol. 5 No. 4, pp. 545-556.

PAS (Publically Available Specification) 96 (2014), Guide to Protecting and Defending Food and Drink from Deliberate Attack, ISBN 978058085537 5, BSI Standards Limited, London.

869 PAS (Publically Available Specification) 1998:2008, Whistleblowing arrangements Code of 870 practice ISBN 9780580509735 BSI Standards Limited, London.

871 Parker, L. E. (1993). "When to fix it and when to leave: Relationships among perceived 872 control, self-efficacy, dissent, and exit". Journal of Applied Psychology, Vol. 78, No. 1, pp. 873 949-959.

874

875

876

877

878

879

880

881

882

883

884

885

886

887

888

889

890

891

892

PCAW (Public Concern at Work) (2016), Available at: http://www.pcaw.co.uk/ (accessed on 28 November 2016)

PCAW (2013) Whistleblowing the inside story. Available at:

http://www.pcaw.co.uk/files/Whistleblowing\%20-\%20the\%20inside\%20story\%20FINAL.pdf (accessed on 28 November 2016)

Philipsen, N.C. and Soeken, D. (2011), "Preparing to blow the whistle: A survival guide for nurses”, The Journal for Nurse Practitioners, Vol 9 No. 9, pp. 740-746.

Ponemon, L. A. (1994),"Whistle-blowing as an internal control mechanism: Individual and organisational considerations", Auditing: A Journal of Practice \& Theory, Vol. Fall 1994, pp. 118-130.

Rothwell, G.R. and Baldwin, J.N. (2006), "Ethical climate theory, whistleblowing and the code of silence in police agencies in the state of Georgia", Journal of Business Ethics, Vol. 70 No. 4, pp. 341-361. 
893 Sarbanes-Oxley Act (2002), "A guide to the Sarbanes-Oxley Act", available at:

894 www.soxlaw.com (accessed 13 March 2016).

895

896 Schultz, D. and Harutyunyan, K. (2015), "Combating corruption: The development of 897 whistleblowing laws in the United States, Europe and Armenia", International Comparative 898 899

Schultz, Jr. J.J., Johnson, D.A., Morris, D. and Dyrnes, S. (1993), “An investigation of the reporting of questionable acts in an international setting", Journal of Accounting Research, Vol. 31 Suppl. 1993, pp. 75-103.

Soeken, D.R. (2014), Don't kill the messenger: How America's valiant whistleblowers risk everything in order to speak out against waste, fraud and abuse in business and government, CreateSpace Independent Publishing Platform, North Charleston, pp. 1-181.

Spink, J., Moyer, D. C., \& Whelan, P. (2016). The Role of the Public Private Partnership in Food Fraud Prevention-includes implementing the Strategy. Current Opinion in Food Science. http://dx.doi.org/doi:10.1016/j.cofs.2016.10.002

911 Spink, J., Moyer, D. C., Park, H., Wu, Y., Fersht, V., Shao, B., \& Edelev, D. (2015).

912 Introducing Food Fraud including translation and interpretation to Russian, Korean, and 913 Chinese languages. Food Chemistry, Vol. 189, No. 1, pp. 102-107.

914

915

916

917

918

919

920

921

922

923

924

925

926

927

928

929

930

931

932

933

934

935

936

937

938

939

Spink, J. and Moyer, D.C. (2011), "Defining the public health threat of food fraud", Journal of Food Science, Vol. 76 No. 9, pp. R157-R163.

Tan, P.M. and Ong, S.F. (2011), "Comparative analysis of whistleblower protection legislation in England, USA and Malaysia", African Journal of Business Management, Vol. 5 No. 27, pp. 11246-11255.

Tang, C.S. and Babich, V. (2014), "Using social and economic incentives to discourage Chinese suppliers from product adulteration”, Business Horizons, Vol. 57 No. 4, pp. 497-508.

Tesco (2016) Whistleblowing Tesco Colleague and Suppliers Protector Line Policy, Available at: https://www.tescoplc.com/assets/files/cms/Resources/Trading_Responsibly/Whistleblowing . pdf Accessed on 27 November 2016

The Economist (2015), "Whistleblowing in Switzerland rough terrain", $15^{\text {th }}$ December, available at: http://www.economist.com/news/business/21679456-two-court-cases-illustratestruggles-employees-who-allege-wrongdoing-rough-terrain (accessed 4 March 2016).

Transparency International's Secretariat (2013), “International principles for whistleblower legislation. Best practices for laws to protect whistleblowers and support whistleblowing in the public interest", available at:

http://www.transparency.org/whatwedo/publication/international_principles_for_whistleblow

940 er_legislation (accessed 6 March 2016). 
941 Trevino, L. K. and Victor, B. (1992), "Peer reporting of unethical behaviour: A social context 942 perspective", Academy of Management Journal, Vol. 35 No. 1, pp. 38-64.

943

944 Vinten, G. (1996), "Corporate communications through whistleblowing”, Corporate

945 Communications, Vol. 1 No. 1, pp. 30-35.

946

947

948

949

950

951

952

953

954

955

956

957

958

959

960

961

962

963

964

965

966

967

968

969

970

971

972

Waytz, A., Dungan, J. and Young, L. (2013), “The whistleblower's dilemma and the fairnessloyalty tradeoff”, Journal of Experimental Social Psychology, Vol. 49 No. 6, pp. 1027-1033.

Withey, M. J., and Cooper, W. H. (1989). "Predicting exit, voice, loyalty, and neglect". Administrative Science Quarterly, Vol. 34, No. 1, pp.521-539.

Williams, P., (2001). Transnational criminal networks. In: Arquilla, J., Ronfeldt, D. (Eds.), Networks and Netwars: The Future of Terror, Crime and Militancy. Rand Corporation, Santa Monica, pp. 61-97.

WIN (2017a) (Whistleblowing International Network), Sapin II first look at how the French are doing whistleblower protection, available at:

https://www.google.co.uk/amp/s/whistleblowingnetwork.org/2017/03/16/sapin-ii-a-first-lookat-how-the-french-are-doing-whistleblower-protection/amp/ (accessed 3 May 2017)

WIN (2017b) (Whistleblowing International Network) Serbia, available at: https://whistlenetwork.files.wordpress.com/2017/01/law-on-protection-ofwhistleblowersfinal.pdf (accessed 3 May 2017)

World Law Group (2012), "Global guide to whistleblowing programs”, available at: file://lha$012 /$ pers-

J/00075EF2/Downloads/WLG\%20Global\%20Guide\%20to\%20Whistleblowing\%20Programs -2012-Revised.pdf (accessed 5 May 2016).

Worth, M. (2013), "Whistleblowing in Europe. Legal protections for whistleblowers in the 973 https://www.transparency.de/fileadmin/pdfs/Themen/Hinweisgebersysteme/EU Whistleblow 974 er_Report final_web.pdf (accessed 4 May 2016).

975

976

977

978

979

980

981

982

983

984

985

986

987

988

989

990

Yeates, J. W. (2012), "Whistle-blowing in the veterinary profession", The Veterinary Journal, Vol. 191, No. 2, pp 147-150.

Zakaria, M. (2015), “Antecedent factors of whistleblowing in organizations”, Procedia Economics and Finance, Vol. 28, No. 1, pp. 230-234

Zhang, J., Zhang, X., Dediu, L. and Victor, C. (2011), "Review of the current application of fingerprinting allowing detection of food adulteration and fraud in China". Food Control, Vol. 22 No. 8, pp. 1126-1135

Zhuang, P. (2012), "Mystery surrounds death of whistleblower Jiang Weisuo", 24 November 2012, South China Morning Post, available at: http:/www.scmp.com/news/china/article/1089540/mystery- surrounds-death-milkwhistleblower-jiang-weisuo (accessed 4 March 2016) 
991 Table 1. Examples of whistleblowing incidents in the food industry

\begin{tabular}{|c|c|c|c|c|c|c|c|}
\hline Year & $\begin{array}{l}\text { Description of } \\
\text { whistleblower }\end{array}$ & $\begin{array}{c}\text { Internal Whistleblower } \\
\text { (WB) }\end{array}$ & $\begin{array}{c}\text { External (Official) } \\
\text { WB }\end{array}$ & $\begin{array}{c}\text { External (Media) } \\
\text { WB }\end{array}$ & Description & Outcome & References \\
\hline $\begin{array}{l}2006 \\
\text { ongoing }\end{array}$ & $\begin{array}{l}\text { Food safety } \\
\text { manager of Nestle }\end{array}$ & $\begin{array}{l}\text { Reported there was an } \\
\text { inadequate process in } \\
\text { validating the nutrient } \\
\text { content of infant formula } \\
\text { biscuits that could result } \\
\text { in babies choking and } \\
\text { incorrectly labelled } \\
\text { packaging. }\end{array}$ & & & $\begin{array}{l}\text { Request for audit of her } \\
\text { department was turned } \\
\text { down. The former food } \\
\text { safety manager is } \\
\text { claiming } \$ 2 \text { million } \\
\text { compensation plus an } \\
\text { allowance for lost } \\
\text { earnings. }\end{array}$ & $\begin{array}{l}\text { Claims of acts of reprisal } \\
\text { including being 'treated like a } \\
\text { child' and being humiliated. } \\
\text { Both the former food safety } \\
\text { manager and Nestle failed to } \\
\text { agree on a settlement and the } \\
\text { case went to trial. }\end{array}$ & $\begin{array}{l}\text { Miller (2015); } \\
\text { The Economist } \\
(2015)\end{array}$ \\
\hline 2008 & $\begin{array}{l}\text { Manager at Peanut } \\
\text { Corporation of } \\
\text { America (PCA) } \\
\text { (Texas processing } \\
\text { plant) }\end{array}$ & $\begin{array}{l}\text { Report to the Chief } \\
\text { Executive Officer (CEO) } \\
\text { of PCA about rodent } \\
\text { infestation and leaky roof. } \\
\text { The CEO did not respond } \\
\text { to the manager. }\end{array}$ & $\begin{array}{l}\text { Manager then } \\
\text { reported to Texas } \\
\text { Department of } \\
\text { Health, and did not } \\
\text { receive response. } \\
\text { Subsequently, } \\
\text { Texas authorities } \\
\text { searched their } \\
\text { database but found } \\
\text { no record of emails } \\
\text { from the manager. }\end{array}$ & $\begin{array}{l}\text { The manager finally } \\
\text { whistleblew to Safe } \\
\text { Tables Our Priority } \\
\text { (STOP) a national } \\
\text { health organisation } \\
\text { and went on Good } \\
\text { Morning America. }\end{array}$ & $\begin{array}{l}\text { The manager was } \\
\text { triggered to whistleblow } \\
\text { when his/her } \\
\text { granddaughter became ill } \\
\text { after eating peanut butter } \\
\text { crackers. }\end{array}$ & $\begin{array}{l}\text { PCA went bankrupt and on } \\
\text { September } 2015 \text {, the former } \\
\text { CEO of PCA was sentenced } \\
\text { to } 28 \text { years in prison. }\end{array}$ & $\begin{array}{l}\text { Basu (2015); } \\
\text { Harris and } \\
\text { Barrett (2009); } \\
\text { Near and Micelli } \\
(2016)\end{array}$ \\
\hline 2008 & Truck drivers (PCA) & & & $\begin{array}{l}\text { Truck drivers } \\
\text { whistleblew to media }\end{array}$ & $\begin{array}{l}\text { Packages of peanut paste } \\
\text { burst in truck and were } \\
\text { later shovelled up and } \\
\text { replaced back in barrels. } \\
\text { Shipment was rejected } \\
\text { by one Georgia } \\
\text { company, but PCA } \\
\text { signed for it and } \\
\text { accepted the delivery }\end{array}$ & & $\begin{array}{l}\text { Harris and } \\
\text { Barrett (2009) }\end{array}$ \\
\hline 2012 & $\begin{array}{l}\text { Local Chinese TV } \\
\text { broadcast }\end{array}$ & & & $\begin{array}{l}\text { Undercover reporting } \\
\text { by media }\end{array}$ & $\begin{array}{l}\text { TV reported that KFC's } \\
\text { supplier (Liuhe Group) } \\
\text { in China added illegal } \\
\text { drugs in chicken feed to } \\
\text { accelerate their growth } \\
\text { cycles. }\end{array}$ & $\begin{array}{l}\text { KFC's products were } \\
\text { boycotted and sales } \\
\text { plummeted } 25 \% \text { by early } \\
2013 \text {. KFC stopped } \\
\text { purchasing chickens from } \\
\text { Liuhe Group. }\end{array}$ & $\begin{array}{l}\text { Tang and Babich } \\
\text { (2014) }\end{array}$ \\
\hline
\end{tabular}




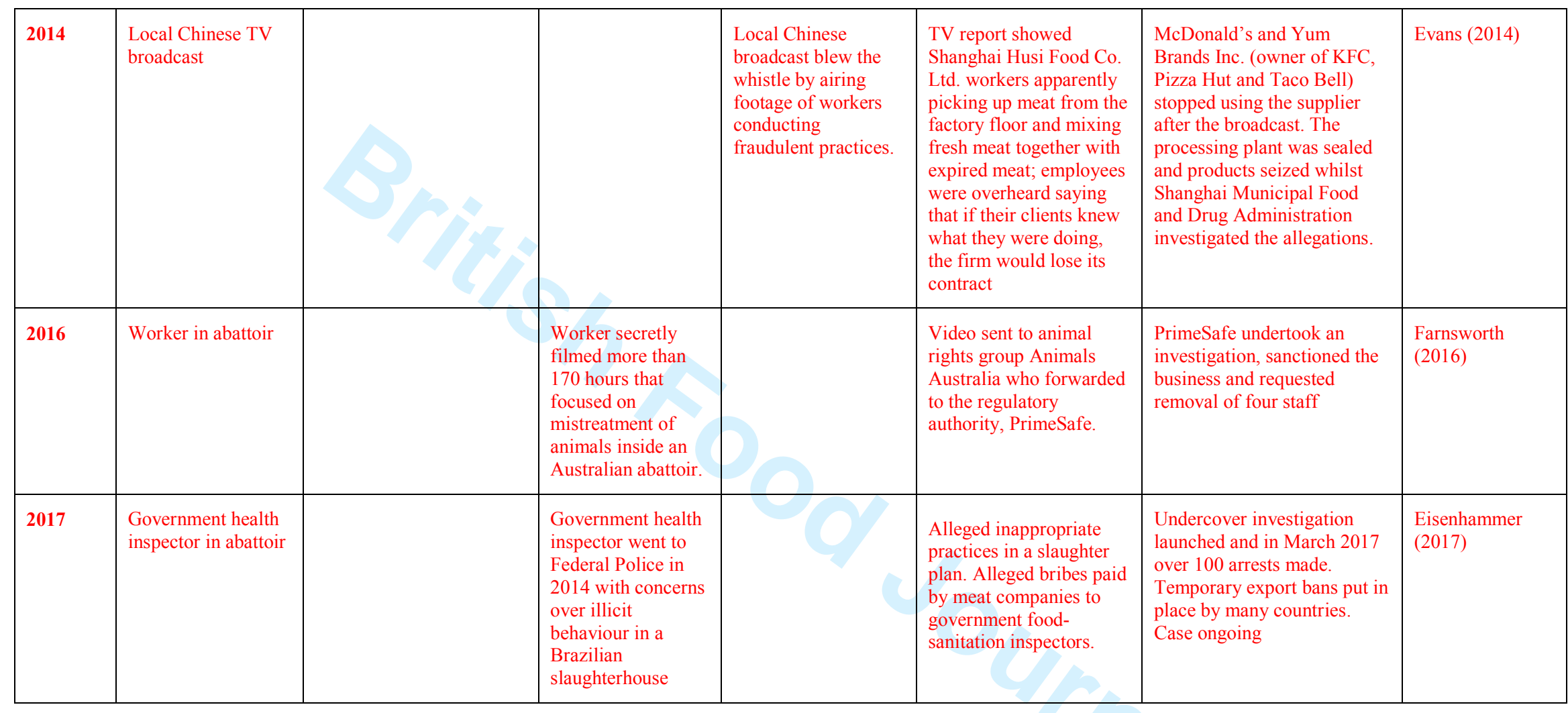


994 Table 2 - Expolink - Incidence of issues (Adapted from Expolink, 2014; Expolink, 2016a; Expolink, 2016b)

\begin{tabular}{|l|l|c|c|c|c|c|c|c|}
\hline \multicolumn{1}{|c|}{ Year } & $\mathbf{2 0 0 9}$ & $\mathbf{2 0 1 0}$ & $\mathbf{2 0 1 1}$ & $\mathbf{2 0 1 2}$ & $\mathbf{2 0 1 3}$ & $\mathbf{2 0 1 4}$ & $\mathbf{2 0 1 6}$ \\
\hline Theft & $10 \%$ & $12 \%$ & $7 \%$ & $7 \%$ & $5 \%$ & $4 \%$ & $4 \%$ \\
\hline Fraud & $8 \%$ & $6 \%$ & $5 \%$ & $4 \%$ & $6 \%$ & $6 \%$ & $5 \%$ \\
\hline Breach of company policy* & $5 \%$ & $5 \%$ & $5 \%$ & $6 \%$ & $8 \%$ & $\mathrm{Nr}$ & $9 \%$ \\
\hline Unprofessional behaviour* & $4 \%$ & $5 \%$ & $5 \%$ & $7 \%$ & $6 \%$ & $6 \%$ & $7 \%$ \\
\hline
\end{tabular}

$\mathrm{Nr}-$ not reported *may not be illegal 
Table 3. Review of existing whistleblowing models and applicability to food settings

\begin{tabular}{|c|c|c|c|c|}
\hline Focus & Model & Description & Potential application in Food Settings & References \\
\hline Public accounting & $\begin{array}{l}\text { The Graham } \\
\text { Model - }\end{array}$ & $\begin{array}{l}\text { Greater perceived seriousness of } \\
\text { wrongdoing, and personal responsibility } \\
\text { and lower perceived personal cost predicted } \\
\text { greater whistleblowing intention. }\end{array}$ & $\begin{array}{l}\text { A positive culture (mood) in food processing environment will } \\
\text { encourage food production workers to have a greater sense of } \\
\text { responsibility hence increased intention to whistleblow. Having } \\
\text { procedures in place in the food business to protect the whistleblower } \\
\text { and effective training, coaching and mentoring of staff will also } \\
\text { increase the likelihood of whistleblowing }\end{array}$ & $\begin{array}{l}\text { Curtis (2006); Graham } \\
\text { (1986); Schultz et al. } \\
\text { (1993) }\end{array}$ \\
\hline Multiple & $\begin{array}{l}\text { Fairness- } \\
\text { loyalty } \\
\text { tradeoff }\end{array}$ & $\begin{array}{l}\text { Individuals who value fairness over loyalty } \\
\text { demonstrates increased willingness to } \\
\text { report wrongdoings. }\end{array}$ & $\begin{array}{l}\text { Workers are motivated to whistleblow in the service of fairness and } \\
\text { justice but can also appear disloyal to colleagues and the teams in } \\
\text { which they operate, hence creating a dilemma that affects } \\
\text { willingness to take action. This dilemma can be mediated by } \\
\text { highlighting internal reporting channels and also ensuring } \\
\text { anonymity to protect whistleblowers. }\end{array}$ & $\begin{array}{l}\text { Dungan et al. (2015); } \\
\text { Waytz et al. (2013) }\end{array}$ \\
\hline Police agencies & $\begin{array}{l}\text { Theory of } \\
\text { Planned } \\
\text { Behaviour } \\
\text { (TPB) }\end{array}$ & $\begin{array}{l}\text { Attitudes, subjective norm and perceived } \\
\text { behavioural control had positive effects on } \\
\text { internal whistleblowing intentions. }\end{array}$ & $\begin{array}{l}\text { Park and Blenkinsopp (2009) supported the relevance of TPB in } \\
\text { whistleblowing intention. TBP is used as the basis of understanding } \\
\text { and enabling whistleblowing intention among food production } \\
\text { workers by influencing perceptions and thus attitude, subjective } \\
\text { norm and perceived behavioural control.. }\end{array}$ & $\begin{array}{l}\text { Park and Blenkinsopp } \\
\text { (2009); Rothwell and } \\
\text { Baldwin (2006) Ajzen } \\
(1985,1991)\end{array}$ \\
\hline Multiple & $\begin{array}{l}\text { Theory of } \\
\text { Reasoned } \\
\text { Action } \\
\text { (TRA) }\end{array}$ & $\begin{array}{l}\text { Prediction of intention through beliefs, } \\
\text { attitude and subjective norms. }\end{array}$ & TRA can be used to predict food workers' intent to blow the whistle. & $\begin{array}{l}\text { Ajzen and Fishbein } \\
\text { (1980); Fishbein and } \\
\text { Ajzen (1975) }\end{array}$ \\
\hline Multiple & $\begin{array}{l}\text { The Henik } \\
\text { model }\end{array}$ & $\begin{array}{l}\text { Model of the factors of influence in the } \\
\text { whistleblowing decision making process } \\
\text { through characterisation of potential } \\
\text { whistleblowers into strategic moral } \\
\text { guardians (SMG); fed-up vigilante (FUV) } \\
\text { and servant of two masters (STM) via the } \\
\text { influence of emotions. }\end{array}$ & $\begin{array}{l}\text { SMG retain their focus on halting wrongful activities, while FUV } \\
\text { shift their focus to restitution. Thus, while anger is present in both } \\
\text { cases, the goals, targets and methods of a whistleblowing disclosure } \\
\text { depend on the source of the anger. }\end{array}$ & Henik (2015) \\
\hline
\end{tabular}


Table 4. Characterisation of actors in the whistleblowing process (Adapted from Henik, 2015; Goldberg et al. 1999)

\begin{tabular}{|l|l|}
\hline \multicolumn{1}{|c|}{ Characterisation } & \multicolumn{1}{|c|}{ Description } \\
\hline $\begin{array}{l}\text { Strategic moral } \\
\text { guardian (SMG) }\end{array}$ & $\begin{array}{l}\text { Individual who focuses on accountability and results and who are motivated by strong extra- } \\
\text { organisational allegiances and emotion (anger) at organisational inaction following their internal } \\
\text { reporting. They seek appropriate mechanisms that will limit personal or professional impact. }\end{array}$ \\
\hline $\begin{array}{l}\text { Fed-up vigilante } \\
\text { (FUV) }\end{array}$ & $\begin{array}{l}\text { Individual who is initially motivated to advocate against wrongful activities by strong extra- } \\
\text { organisational principles and is driven by revenge and catharsis, justice and restitution. As they } \\
\text { may have already suffered retribution they can feel they have nothing left to lose or fear. }\end{array}$ \\
\hline $\begin{array}{l}\text { Servant of Two } \\
\text { Masters (STM) }\end{array}$ & $\begin{array}{l}\text { Individual trying to manage conflicting values of potentially whistleblowing in order to protect } \\
\text { victims or report wrongdoing and alternatively taking no action so that they can continue to } \\
\text { observe activities but this might bring feelings of shame or regret. }\end{array}$ \\
\hline
\end{tabular}


Table 5. Causal factors for whistleblowing or to remain silent and associated countermeasures (Adapted from Yeates, 2012)

\begin{tabular}{|c|c|c|c|c|}
\hline \multirow[t]{2}{*}{ Factors } & \multirow[t]{2}{*}{ Action } & \multirow[t]{2}{*}{ Inaction } & \multicolumn{2}{|c|}{ Food Crime Management System } \\
\hline & & & Transactional & Transformational \\
\hline \multicolumn{5}{|c|}{ Individual } \\
\hline \multirow[t]{3}{*}{ Personal characteristics } & Moral purpose & Weakness of will & \multirow{6}{*}{$\begin{array}{l}\text { Awareness training during } \\
\text { induction; Ongoing and } \\
\text { updated training in } \\
\text { examples of food crime. } \\
\text { Documented and } \\
\text { implemented } \\
\text { whistleblowing policy with } \\
\text { associated audit and } \\
\text { verification programme }\end{array}$} & \multirow{6}{*}{$\begin{array}{l}\text { Leading by example. } \\
\text { Encouraging supportive, sense of } \\
\text { belonging with a specific focus on } \\
\text { team and group culture with } \\
\text { common purpose. }\end{array}$} \\
\hline & Empathy for victims & Empathy for suspected respondent & & \\
\hline & $\begin{array}{l}\text { Loyalty to company and concern over } \\
\text { wrongdoer and their impact on the } \\
\text { organisation, staff and customers. }\end{array}$ & $\begin{array}{l}\text { Loyalty to wrongdoer who may be } \\
\text { difficult to differentiate from the company }\end{array}$ & & \\
\hline \multirow[t]{2}{*}{ Awareness } & $\begin{array}{l}\text { Knowledge of what is illegal, unethical } \\
\text { or immoral behaviour }\end{array}$ & $\begin{array}{l}\text { Ignorance or uncertainty about what is } \\
\text { illegal, unethical or immoral behaviour }\end{array}$ & & \\
\hline & Knowledge of reporting procedure & $\begin{array}{l}\text { Ignorance or uncertainty of reporting } \\
\text { procedure }\end{array}$ & & \\
\hline \multirow[t]{2}{*}{ Duty } & Sense of duty to report wrongdoing & $\begin{array}{l}\text { Belief that others will report the } \\
\text { wrongdoing so inaction is acceptable }\end{array}$ & & \\
\hline & $\begin{array}{l}\text { Severity of wrongdoing (Near et al. } \\
\text { 2004; Caillier, 2016) }\end{array}$ & $\begin{array}{l}\text { Perception that wrongdoing is not } \\
\text { significant. }\end{array}$ & & \\
\hline \multicolumn{5}{|c|}{ Situational and Organisational factors } \\
\hline \multirow[t]{2}{*}{ Consequences } & $\begin{array}{l}\text { Positive impact e.g. to reduce future } \\
\text { wrongdoing }\end{array}$ & $\begin{array}{l}\text { Fear of negative consequences e.g. } \\
\text { retaliation to whistleblowers }\end{array}$ & \multirow{2}{*}{$\begin{array}{l}\text { Protect confidentiality of } \\
\text { whistleblower through } \\
\text { effective procedures. }\end{array}$} & \multirow{2}{*}{$\begin{array}{l}\text { Encourage supportive, sense of } \\
\text { belonging with a specific focus on } \\
\text { organisational culture }\end{array}$} \\
\hline & Faith in the system & $\begin{array}{l}\text { Lack of faith in system (e.g. employer is } \\
\text { perceived to be non-responsive to } \\
\text { complaints) (Nitsch et al., 2005) }\end{array}$ & & \\
\hline
\end{tabular}




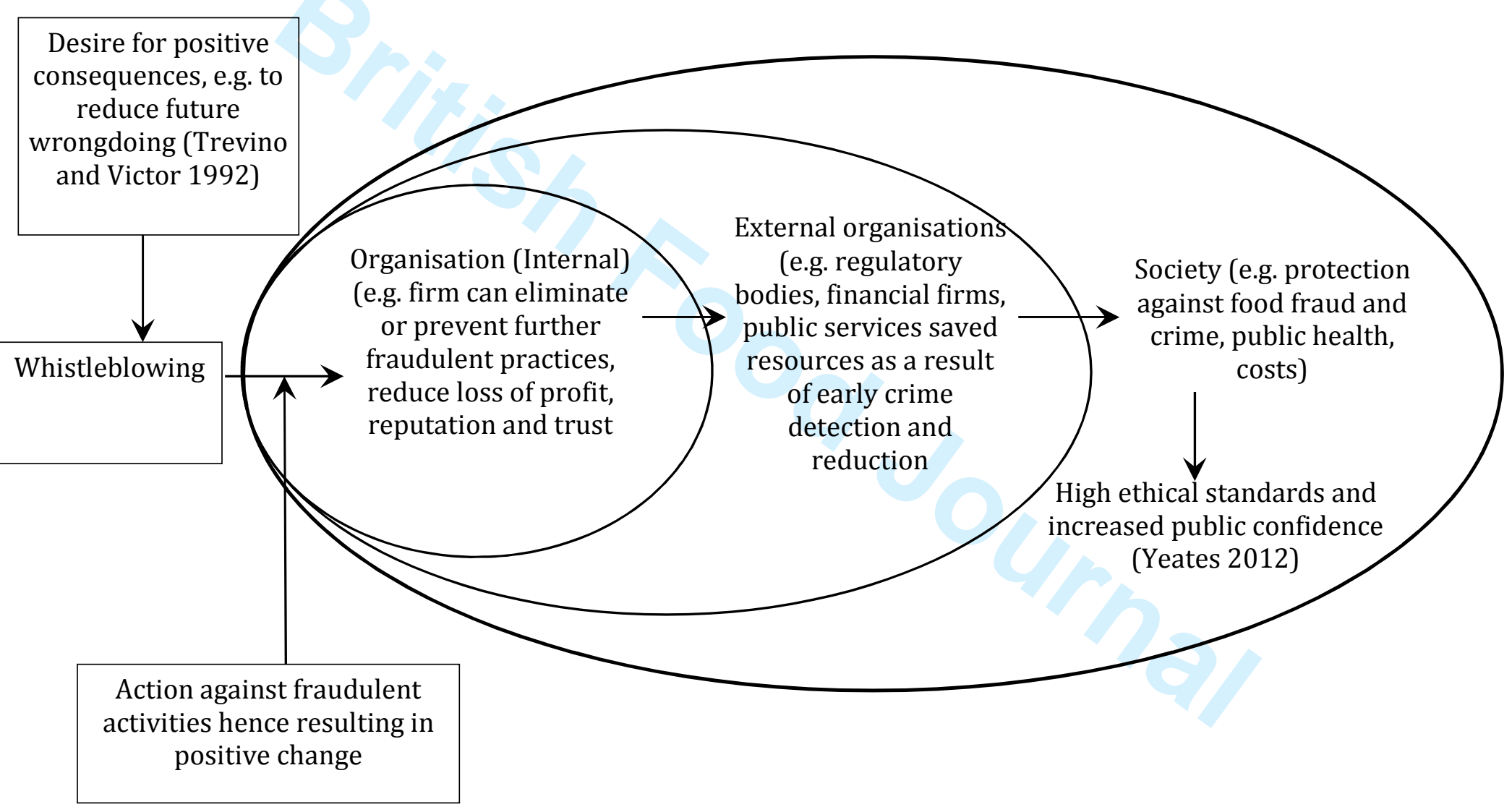

Figure 1. Positive consequences of whistleblowing (Adapted from Bowers et al., 2012) 


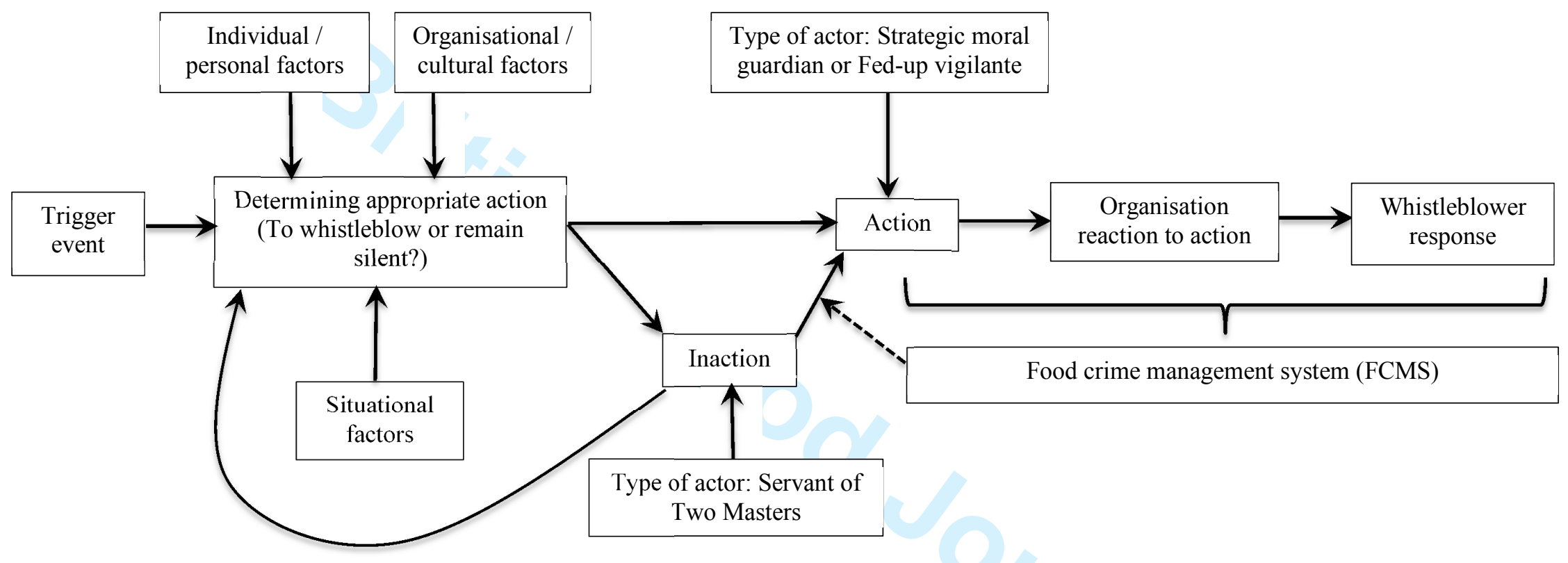

Figure 2. Whistleblowing strategies within the 5 stage whistleblowing model (Adapted from Henik 2015) 